\title{
TANGGUNGJAWAB SOSIAL PERUSAHAAN DAN TINGKAT KEBERDAYAAN EKONOMI RUMAH TANGGA
}

\author{
Sumaryo \\ Jurusan Sosial Ekonomi Pertanian/ Agribisnis, Fakultas Pertanian Universitas Lampung \\ Bandar Lampung 35145 Indonesia Telepon/Fax: +62 0721770347
}

Diterima 22 September 2011 / Disetujui 1 Nopember 2011

\begin{abstract}
The objectives of the study are: (1) to identify the influence of CSR implementation toward the community behavior progress on their business, (2) to identify the influence of CSR implementation to the household economic capability, and (3) to formulate and to design strategy to improve the community business capability and their income. LISREL was used to formulate the Structural Equation Modelling of CSR implementation. The important results show: (1) facilitators' competency and supporting factors are significantly influence to the community business capability, while individual characters and quality program do not significantly influence to the community business capability, (2) the community business capability does significantly influence to the level of houseold economic capability, (3) the "participative CSR" is recomemmeded as a model of CSR implementation.
\end{abstract}

Keywords: social responsibility, CSR, household, economic capability, business

\begin{abstract}
Abstrak: Penelitian ini bertujuan mengidentifikasi pengaruh implementasi program CSR terhadap perubahan perilaku berusaha masyarakat, mengidentifikasi pengaruh implementasi CSR terhadap keberdayaan ekonomi rumahtangga, dan merumuskan dan merancang strategi untuk meningkatkan kapasitas berusaha dan pendapatan masyarakat. Untuk memformulasikan model persamaan struktural implementasi program CSR digunanakan LISREL. Hasil penting penelitian menunjukkan bahwa: Pertama, kompetensi fasilitator dan faktor pendukung program CSR berpengaruh nyata terhadap perilaku berusaha masyarakat; Kedua, perilaku berusaha masyarakat berpengaruh nyata terhadap tingkat keberdayaan ekonomi rumahtangga; Ketiga, "CSR partisipatif" disarankan sebagai model implementasi CSR.
\end{abstract}

Kata kunci: tanggungjawab sosial, CSR, keberdayaan ekonomi, rumah tangga, bisnis

\section{PENDAHULUAN}

Paradigma pembangunan saat ini telah diwarnai konsep pemberdayaan yang melibatkan pemerintah, swasta, dan masyarakat, sehingga ketiga pihak memiliki tanggung-jawab yang seimbang dalam mencapai tujuan pembangunan di segala bidang. Mereka harus bersinergi dalam perencanaan, pelaksanaan, dan penilaian terhadap hasil-hasil pembangunan yang dilaksanakan. Pemerintah dan pemerintah daerah diharapkan mampu mengkoordinasikan berbagai program atau kegiatan yang ada, masyara- kat diharapkan berpartisipasi aktif, dan swasta (terutama perusahaan atau korporasi yang mengeksploitasi sumberdaya alam dan sumberdaya manusia di suatu wilayah) seharusnya berkontribusi secara wajar di dalam pembangunan daerah sebagai implementasi tanggungjawab sosialnya.

APBD Lampung tahun anggaran 2007 mencapai nilai Rp1,6 triliun dengan total penerimaan sebesar Rp1,066 trilyun dan total PAD Rp485 juta, dari nilai tersebut selama ini peran dan kontribusi perusahaan dan BUMN kurang optimal. Hal itu disebabkan peraturan yang harus dilakukan oleh perusahaan dan BUMN 
belum dijalankan sebagaimana mestinya. Potensi peran perusahaan dan BUMN di Lampung cukup besar, mengingat jumlah perusahaan besar dan menengah yang beroperasi di Provinsi Lampung pada tahun 2005 mencapai 194 buah (BPS Lampung, 2009). Perusahaanperusahaan tersebut telah lama beroperasi dan mengeksploitasi kekayaan setempat (terutama lahan pertanian) sebagai salah satu faktor produksi yang dominan.

Pemerintah menegaskan bahwa setiap perusahaan memiliki kewajiban untuk bertanggungjawab akan kesejahteraan dan peningkatan taraf hidup masyarakat di sekitarnya. Tanggungjawab yang dibebankan kepada perusahaan tersebut dituangkan dalam Keputusan Menteri BUMN Nomor: KEP-236/MBU/2003 tanggal 17 Juni 2003 dan Undang-Undang Perseroan Terbatas Nomor: 40 Tahun 2007 yang ditetapkan bulan Juli 2007. Pada pasal 74 dinyatakan:

"(1) Perseroan yang menjalankan kegiatan usahanya di bidang dan/atau berkaitan dengan sumber daya alam wajib melaksanakan tanggungjawab sosial dan lingkungan; (2) Tanggungjawab sosial dan lingkungan sebagaimana dimaksud pada ayat (1) merupakan kewajiban Perseroan yang dianggarkan dan diperhitungkan sebagai biaya Perseroan yang pelaksanaannya dilakukan dengan memperhatikan kepatutan dan kewajaranan".

Di masyarakat, terutama kalangan pengusaha terbagi menjadi dua kelompok yang berseberangan dalam menafsirkan Pasal 74 tentang pelaksanaan tanggungjawab sosial perusahaan. Di satu kelompok, setuju terhadap kewajiban melaksanakan tanggungjawab sosial bagi perusahaan yang memanfaatkan sumberdaya alam, di kelompok lain tidak setuju terhadap formalisasi aturan tersebut. Namun demikian, jauh sebelum disahkannya Undang-undang tersebut, beberapa perusahaan nasional dan multinasional telah melaksanakan tanggungjawab sosialnya (corporate social responsibility/CSR) melalui beragam program atau kegiatan yang dilakukan secara mandiri atau melibatkan pihak ketiga.

Konsep tanggungjawab sosial perusahaan (Corporate Social Responsibility/CSR) merupakan suatu pendekatan perubahan atau pengembangan masyarakat khususnya peningkatan sumberdaya manusia yang dilakukan oleh sua- tu perusahaan sebagai bagian dari tanggungjawab sosialnya. Pendekatan ini bertujuan agar masyarakat turut terlibat atau menjadi bagian dari perusahaan tersebut dan menikmati manfaat dari keberadaan perusahaan di suatu wilayah tertentu. Pendekatan pengembangan masyarakat tersebut mengacu pada konsep Community Development yang kaitannya dapat dilihat dari perspektif "economic", "social justice" maupun perspektif "ecological", sebagai konsep yang dikenalkan oleh European Union dimana perusahaan memadukan aspek sosial dan lingkungan dalam kegiatan bisnisnya serta dalam interaksinya dengan pemangku kepentingan (stakeholders) berdasarkan prinsip sukarela (Anonim, 2005:5).

Dalam perspektif social justice masyarakat sekitar perusahaan turut diberdayakan, sehingga terjadi proses empowerment, melalui kegiatan-kegiatan pelatihan (capacity building) yang sesuai dengan kebutuhan masyarakat. Selain itu, masyarakat juga dibantu fasilitas (dana, sarana, dan prasarana) agar mereka dapat bekerja dan menciptakan peluang usaha (creating opportunities) untuk meningkatkan kualitas kehidupannya. Dari segi perspektif "ecological" masyarakat diharapkan juga turut menjaga kelestarian lingkungan demi keberlanjutan (sustainability) perusahaan tersebut.

Kalangan industri Kanada menyatakan bahwa CSR merupakan upaya yang ditempuh perusahaan mencapai keseimbangan ekonomi, lingkungan, dan sosial sesuai harapan para pemegang saham dan pemangku kepentingan (CSR is the way a company achieves a balance or integration of economic, environmental, and social imperatives while at the same time addressing shareholder and stakeholder expectations) (Industry Canada, 2009). Hal ini sejalan dengan landasan teoritik dari Elkington (Pambudi, 2005:19) bahwa CSR adalah aktivitas yang mengejar triple buttom line yang terdiri dari profit, people, dan planet (3P). Selain mengejar keuntungan untuk kepentingan pemegang saham (profit), perusahaan juga harus memperhatikan pemangku kepentingan seperti pemenuhan kesejahteraan masyarakat (people), serta berpartisipasi aktif dalam menjaga kelestarian lingkungan (planet). Sebagai konsekuensinya implementasi program CSR di lingkungan masyarakat 
juga dapat didasarkan pada konsep "local resource based" sebab kehadiran perusahaan di suatu wilayah memanfaatkan berbagai aset masyarakat, terutama prasarana transportasi. Hal ini terkait dan sejalan dengan prinsip community ownership. Dengan demikian diharapkan perusahaan juga ikut memelihara dan merasa memiliki kekayaan yang berupa prasarana di suatu wilayah. Pendekatan CSR diharapkan dapat menciptakan multiplier effect bagi masyarakat lokal secara luas. Keberadaan perusahaan diharapkan akan menjadi pendorong aktivitas dan pertumbuhan ekonomi di suatu wilayah.

Beberapa batasan tersebut dapat dipahami bahwa tanggung jawab perusahaan yang bersifat ekonomis, teknis (lingkungan), dan sosial dapat tercapai secara bersama-sama apabila perusahaan tersebut mau mengimplementasikan tanggungjawab sosialnya secara bijaksana. Semua manfaat yang dapat dipetik perusahaan pada akhirnya dapat membantu kelangsungan usaha (sustainability) perusahaan. Hubungan sosial perusahaan yang meningkat dengan masyarakat sekitar akan menambah rasa aman terhadap gangguan dari masyarakat sekitar.

Menurut Frederick et.al. (1988:28-29) ada dua prinsip yang mendasari ide moderen tentang CSR, yaitu prinsip karitatif (charity principle) dan prinsip pelayanan (stewardship principle). Prinsip karitatif menganjurkan agar dalam masyarakat si kaya membantu si miskin (yang kurang beruntung), dengan demikian perusahaan harus memberikan bantuan secara sukarela kepada perorangan dan kelompok yang membutuhkan. Hal ini dilakukan oleh perusahaan melalui kedermawanan perusahaan (corporate philanthropy) dan aksi pemasaran sosial. Prinsip pelayanan mengajarkan agar pengelola perusahaan melihat dirinya sebagai pelayan untuk melakukan kegiatan di masyarakat yang berkepentingan dengannya, sehingga perusahaan harus bertindak sebagaimana dipercayakan oleh publik, serta memperhatikan keinginan semua pihak yang terpengaruh oleh keputusan dan kebijakan perusahaan. Hal ini dilakukan perusahaan dengan membangun saling ketergantungan antara perusahaan dan masyarakat, serta berlaku adil terhadap keinginan dan kebu- tuhan berbagai kelompok di dalam masyarakat.

Kotler dan Lee (2005:3) menyatakan bahwa CSR merupakan suatu komitmen untuk meningkatkan kesejahteraan masyarakat sebagai pertimbangan dalam praktik bisnis dan kontribusi dari sumberdaya perusahaan. Inti dari pengertian tersebut tidak mengacu pada aktivitas bisnis yang diatur oleh peraturan perundangan yang berlaku, namun lebih pada komitmen kerelawanan perusahaan sehingga dipilih dan diimplementasikan dalam praktik bisnisnya.

Pandangan yang lebih komprehensif mengenai CSR yang kemudian disebut sebagai "teori Piramida CSR" dikemukakan oleh Carrol (Nursahid, 2006:7) bahwa tanggungjawab sosial perusahaan dapat dilihat berdasarkan empat jenjang (ekonomis, hukum, etis, dan filantropis) yang merupakan satu kesatuan. Untuk memenuhi tanggungjawab ekonomis, sebuah perusahaan harus menghasilkan laba sebagai pondasi untuk mempertahankan perkem-bangan dan eksistensinya. Hal ini sejalan dengan pendapat Drucker (Nursahid, 2006:8) yang cukup terkenal bahwa "business is business", sebab inti kegiatan setiap perusahaan adalah berusaha mencari keuntungan. Namun demikian dalam menggapai keuntungan tersebut perusahaan harus bertanggungjawab secara hukum dengan mentaati aturan hukum yang berlaku. Perusahaan juga harus bertanggunjawab secara etis, perusahaan harus mempraktikkan hal-hal yang baik dan benar sesuai dengan nilai etika dengan nilai-nilai atau norma-norma masyarakat sebagai rujukan bagi perusahaan dalam menjalankan bisnisnya. Perusahaan juga mempunyai tanggungjawab filantropis yang mensyaratkan agar perusahaan memberikan kontribusi kepada masyarakat agar kualitas hidup masyarakat meningkat sejalan dengan perkembangan bisnis perusahaan.

Dalam pelaksanaannya, Nugraha, $d k k$. (2005) menyatakan bahwa CSR mempunyai lima pilar aktivitas. Pertama, building human capital; secara internal perusahaan dituntut menciptakan dan meningkatkan kapasitas sumber daya manusia (SDM) yang handal; secara eksternal perusahaan dituntut untuk melakukan pemberdayaan masyarakat, yang biasanya dilaksanakan melalui community development. 
Kedua, strengthening economies; perusahaan dituntut untuk tidak kaya sendiri, komunitas di lingkungannya miskin. Mereka harus memberdayakan ekonomi komunitas sekitar. Ketiga, assesing social cohesion; perusahaan dituntut untuk menjaga keharmonisan dengan masyarakat sekitarnya agar tidak menimbulkan konflik. Keempat, encouraging good governance; dalam menjalankan bisnisnya perusahaan harus menjalankan tata kelola bisnis dengan baik. Kelima, protecting the environment; perusahaan harus berusaha keras menjaga kelestarian lingkungan.

Dalam proses reformasi Indonesia menuju masyarakat sipil dan demokrasi seperti sekarang ini, selayaknya korporasi mempunyai tanggung jawab sosial, melalui investasi sosial dalam bentuk pembangunan komunitas untuk turut mendemokratiskan masyarakat sipil. Untuk itu berbagai program pemberian dana bantuan seharusnya dilakukan secara selektif dengan prinsip bottom up. Dengan demikian program CSR semestinya dirumuskan dan dilaksanakan dengan melibatkan masyarakat sekitar perusahaan sebagai sasaran kegiatan. Undangundang Nomor 40 Tahun 2007 tentang Perseroan Terbatas melalui pasal 74 berusaha mengatur pelaksanaan CSR. Hal tersebut mendapat tanggapan yang intinya dapat dikelompokkan menjadi dua, mereka yang setuju dan mereka yang tidak setuju dengan adanya pengaturan terhadap pelaksanaan CSR.

Sumarto (2007) menyatakan bahwa CSR sebagai bentuk kepedulian tidak mungkin diatur secara legal, namun bila CSR dianggap sebagai kewajiban dapat diatur oleh negara. Banyak perusahaan menganggap bahwa realisasi CSR yang selama ini diwujudkan dalam program pengembangan masyarakat (community development) dilakukan karena kepedulian perusahaan sebagai makhluk sosial (corporate citizenship). Karena CSR merupakan kepedulian, maka keberadaan peraturan yang mewajibkannya menjadi tidak relevan. Dalam realitanya, proses produksi perusahaan menciptakan externality, kehadirannya melegitimasi negara untuk mewajibkan perusahaan menginternalisasikan guna meminimalkan dampak negatif keberadaan perusahaan pada masyarakat. Dengan demikian, CSR dapat ditafsirkan sebagai kewa- jiban. Sebagai konsekuensinya, pilihan pemaknaan CSR sebagai kewajiban atau kepedulian menimbulkan implikasi yang berbeda.

Keberadaan perusahaan di suatu wilayah seharusnya juga mempertimbangkan manfaat yang dapat dirasakan masyarakat, khususnya di sekitar perusahaan. Dalam perspektif social justice masyarakat sekitar perusahaan juga ikut diberdayakan, sehingga terjadi proses empowerment, melalui kegiatan-kegiatan pelatihan (capacity building) sesuai dengan kebutuhan masyarakat. Selain itu, masyarakat juga dibantu fasilitas (dana, sarana, dan prasarana) agar mereka dapat bekerja dan menciptakan peluang usaha (creating opportunities) untuk meningkatkan kualitas kehidupannya. Dari segi perspektif "ecological" masyarakat diharapkan juga turut menjaga keberlanjutan (sustainability) perusahaan tersebut.

Pendekatan CSR tersebut juga didasarkan pada konsep "local resource based" sebab kehadiran perusahaan di suatu wilayah memanfaatkan berbagai aset masyarakat, terutama prasarana transportasi. Hal ini terkait dan sejalan dengan prinsip community ownership. Perusahaan diharapkan juga ikut memelihara dan merasa memiliki kekayaan yang berupa prasarana di suatu wilayah. Pendekatan CSR diharapkan dapat menciptakan multiplier effect bagi masyarakat lokal secara luas. Keberadaan perusahaan diharapkan menjadi pendorong aktivitas dan pertumbuhan ekonomi di suatu wilayah.

Perusahaan-perusahaan besar di Indonesia dan beberapa perusahaan agroindustri di Provinsi Lampung telah melaksanakan sebagian tanggungjawab sosialnya melalui upaya pembangunan wilayah maupun upaya pemberdayaan ekonomi masyarakat sekitarnya. Dalam implementasi program CSR, masyarakat sekitar perusahaan sebagai sasaran program dilibatkan dalam perencanaan kegiatannya. Identifikasi kebutuhan masyarakat sekitar perusahaan merupakan langkah awal dalam implementasi program CSR. Keberhasilan upaya pemberdayaan ekonomi masyarakat tersebut dapat dipengaruhi oleh berbagai peubah, baik peubah internal individu masyarakat, maupun peubah eksternal seperti dinamika kelompok masyara- 
kat, kualitas program, maupun kualitas pendukung lainnya. Selama ini penelitian yang mengkaji pelaksanaan program CSR oleh perusahaan-perusahaan dan seberapa besar kontribusinya dalam meningkatkan kesejahteraan masyarakat sekitarnya relatif jarang dilakukan. Beberapa perusahaan yang sudah melaksanakan pemberdayaan ekonomi masyarakat belum melakukan koordinasi di antara mereka, sehingga perlu dicari model pemberdayaan ekonomi masyarakat yang paling efektif dalam meningkatkan keberdayaan ekonomi masyarakat sekitar perusahaan.

Permasalahan penelitian ini dapat dirumuskan sebagai berikut: (1) Apakah implementasi CSR mampu mengubah pengetahuan, keterampilan, dan sikap masyarakat dalam berusaha? (2). Apakah implementasi CSR dapat mempengaruhi tingkat keberdayaan ekonomi rumah tangga masyarakat sekitar perusahaan?

Penelitian ini bertujuan untuk: (1) Mengkaji pengaruh pelaksanaan program CSR terhadap peningkatan pengetahuan, keterampilan, dan sikap masyarakat sasaran dalam berusaha. (2). Mengkaji pengaruh kegiatan CSR terhadap tingkat keberdayaan ekonomi rumah tangga masyarakat sekitar perusahaan. (3) Merumuskan konsep model struktural pemberdayaan ekonomi masyarakat berdasarkan peubah-peubah yang diteliti yang sesuai bagi pelaksanaan CSR oleh perusahaan di Provinsi Lampung.

\section{METODE PENELITIAN}

Penelitian ini merupakan penelitian survei, yakni penelitian yang mengambil sampel dari satu populasi dan menggunakan kuisioner sebagai alat pengumpulan data pokok. Survei dilakukan untuk memperoleh data awal perusahaan-perusahaan yang melaksanakan program CSR serta masyarakat sasaran program tersebut.

Lokasi penelitian ini adalah di wilayah Provinsi Lampung. Penelitian dilakukan pada tahun 2009-2010. Secara administratif, lokasi penelitian termasuk wilayah Kabupaten Lampung Tengah, dan Kabupaten Pesawaran. Populasi penelitian adalah anggota kelompok masyarakat desa sekitar perusahaan yang menjadi sasaran pemberdayaan ekonomi melalui usaha penggemukan sapi potong, budidaya tanaman singkong, pembinaan usaha menjahit, budidaya lele dumbo, budidaya jamur tiram, dan budidaya tanaman kakao. Sampel penelitian berjumlah 200 orang.

Pengumpulan data dilakukan dengan teknik wawancara menggunaan kuisioner yang telah disiapkan. Wawancara mendalam dilakukan terhadap ketua kelompok, kepala kampung, tokoh masyarakat, dan pihak manajemen perusahaan. Analisis data menggunakan teknik analisis deskriptif, analisis korelasional, dan dilanjutkan dengan analisis Structural Equation Modelling (SEM) yang dikenal dengan istilah Model Persamaan Struktural (Supranto, 2004: 220; Solimun, 2002:65-84, Ghozali dan Fuad, 2005: 3).

\section{HASIL DAN PEMBAHASAN}

Berdasarkan sebagian output LISREL menunjukkan bahwa nilai chi-kuadarat $=214,39$, dan derajat bebas, $\mathrm{df}=199$ dengan $p$-value $=0,21609$ $(\mathrm{P}>0.10)$. Hal ini berarti bahwa model fit dengan data. Ukuran lain seperti RMSEA, RMR, dan GFI juga sudah memenuhi batas ambang yang diizinkan masing-masing di bawah 0,08, 0,05, dan di atas 0,90.

Berdasarkan output LISREL, besarnya pengaruh antarpeubah yang diteliti secara ringkas disajikan pada Tabel 1.

Besarnya pengaruh antarpeubah terikat dapat kita ketahui dari nilai Standardized total effect on $Y$ (Tabel 2).

Besarnya taksiran parameter dalam persamaan struktural disajikan pada Gambar 1. Secara matematis model implementasi CSR diformulasikan sebagi berikut: (1) $\begin{aligned} Y_{1}= & 0,0456 X_{1}+0,0343 X_{2}+0,1861 X_{3}+ \\ & 0,3791 X_{4}\end{aligned}$

Perilaku Berusaha $=0.0456$ karakter individu + 0.0343 kualitas program CSR + 0,1861 kompetensi fasilitator +0.3791 faktor pendukung

(2) $\mathrm{Y}_{2}=0,8788 \mathrm{Y}_{1}$

Tingkat keberdayaan ekonomi $=0,8788$ tingkat perilaku berusaha 
Tabel 1. Pengaruh antarpeubah dalam Model

\begin{tabular}{llrrrr}
\hline Peubah tidak bebas & Peubah bebas & $\begin{array}{l}\text { Koefisien } \\
\text { (Unstan- } \\
\text { dardized })\end{array}$ & $\begin{array}{l}\text { Koefisien } \\
\text { (Standar- } \\
\text { dized })\end{array}$ & Nilai-t & Keterangan \\
\hline $\begin{array}{l}\text { Dinamika Kelompok } \\
\left(\mathrm{X}_{5}\right)\end{array}$ & Kualitas Program CSR $\left(\mathrm{X}_{2}\right)$ & $-0,0396$ & $-0,0585$ & $-0,81$ & Tidak nyata \\
Perilaku & Karakter Individu $\left(\mathrm{X}_{1}\right)$ & & & & Tidak nyata \\
Berusaha $\left(\mathrm{Y}_{1}\right)$ & Kualitas Program CSR $\left(\mathrm{X}_{2}\right)$ & 0,0165 & 0,0456 & 0,70 & Tidak nyata \\
& Kompetensi Fasilitator $\left(\mathrm{X}_{3}\right)$ & 0,0036 & 00343 & 0,52 & Nyata \\
& Faktor Pendukung $\left(\mathrm{X}_{4}\right)$ & 0,0653 & 0,1861 & 2,88 & Nyata \\
Tingkat & Karakter Individu $\left(\mathrm{X}_{1}\right)$ & $-0,0273$ & $-0,1530$ & $-3,96$ & Nyata \\
Keberdayaan & Faktor Pendukung $\left(\mathrm{X}_{4}\right)$ & $-0,0106$ & $-0,1243$ & $-2,95$ & Nyata \\
Ekonomi $\left(\mathrm{Y}_{2}\right)$ & & & & & \\
\hline
\end{tabular}

Implikasi dari model pemberdayaan ekonomi masyarakat melalui implementasi program CSR adalah sebagai berikut:

(1) Untuk meningkatkan perilaku berusaha (pengetahuan, keterampilan, dan sikap) ke arah nositif. maka kualitas nrogram C.SR. komneten- perusahaan dalam menjembatani program perusahaan di masyarakat sekitar perusahaan. Fasilitator harus mampu berperan sebagai guru, penasehat, dan penganalisis masalah khalayak sasaran dengan kemampuan yang memadai dalam hal herkomınikasi dan hersikan

Tabel 2. Pengaruh Antarpeubah Terikat dalam Model

\begin{tabular}{lccc}
\hline \multicolumn{1}{c}{ Peubah } & $\begin{array}{c}\text { Perilaku Berusaha } \\
\left(\mathbf{Y}_{\mathbf{1}}\right)\end{array}$ & $\begin{array}{c}\text { Tingkat Keberdayaan Ekonomi } \\
\left(\mathbf{Y}_{\mathbf{2}}\right)\end{array}$ & $\begin{array}{c}\text { Keterangan } \\
\text { Perilaku Berusaha }\left(\mathrm{Y}_{1}\right)\end{array}$ \\
Dinamika Kelompok $\left(\mathrm{X}_{5}\right)$ & - & 0,8788 & Nyata \\
Nilai- $\underline{\underline{t}}$ & 0,0958 & - & Tidak nyata \\
\hline
\end{tabular}




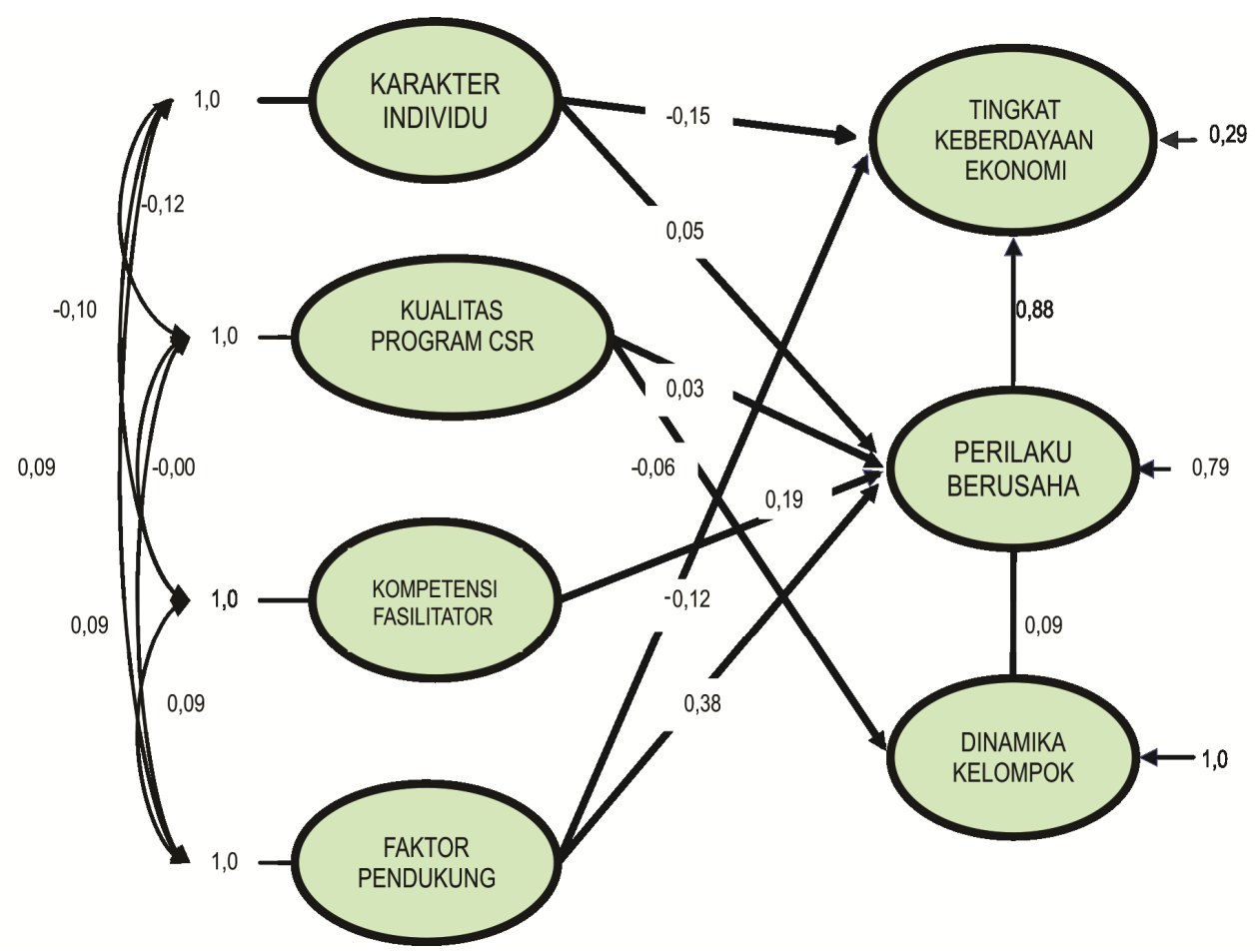

Chi-Square $=214,39, \mathrm{df}=199, \mathrm{P}$-value=0,21609, $\mathrm{RMSEA}=0,020$

Gambar 1. Taksiran Parameter dalam Persamaan Struktural

usaha menjahit pakaian, usaha budidaya ikan lele, usaha budidaya jamur tiram, dan usaha budidaya kakao harus ditingkatkan melalui proses pelatihan dan pendampingan dari pihak perusahaan dan dinas instansi terkait.

(3) Untuk meningkatkan pengetahuan, keterampilan, dan sikap ke arah positif juga dapat ditempuh melalui upaya meningkatkan dinamika kelompok. Sasaran program CSR yang difokuskan melalui kelompok-kelompok masyarakat (kelompok tani, kelompok peternak, dan sebagainya) harus dibina dan didampingi agar kelompok dapat dijadikan wahana belajar, wahana produksi, dan wahana pengambilan keputusan bagi anggotanya.

Berdasarkan hasil analisis dan berbagai temuan serta kerangka berfikir peneliti, berikut disajikan strategi implementasi model tersebut. Suatu model harus memiliki minimal dua ksriteria (Yollies, 1996). Pertama, suatu model harus bersifat dinamik, artinya model harus bersfat responsif dan adaptif terhadap segala bentuk perubahan; hubungan diantara berbagai komponen yang ada dalam model harus saling mendukung. Kedua, model harus memiliki probability, artinya model harus memberikan peluang bagi pengembangan sistem yang lebih maksimal.

Pelaksanaan strategi pemberdayaan masyarakat tersebut dilakukan secara bertahap, dimulai dari tahap awal sampai pada tahap evaluasi keberhasilan (outcome dan impact). Model tersebut diberi nama "CSR Partisipatif", hal ini didasarkan atas pertimbangan pokok berikut:

(1) Implementasi CSR akan berhasil bila direncanakan dengan baik. Proses pencanaan merupakan bagian program yang tidak dapat dihilangkan.

(2) Implementasi program CSR oleh perusahaan harus melibatkan semua pemangku kepentingan dalam setiap tahap kegiatan.

(3) Keberhasilan program CSR sangat ditentukan oleh kesesuaian program dengan kebutuhan masyarakat, sehingga keterlibatan masyarakat dalam penyusunan program tidak dapat diabaikan. 
rapa besar komitmen perusahaan dalam melaksanakan tanggungjawab sosialnya. Namun demikian, kendala yang dihadapi adalah akuntabilitas manajemen perusahaan yang belum "go public" dalam melaporkan atau menginformasikan jumlah keuntungan bersih perusahaan setiap tahunnya. Sebagai badan usaha yang belum "go public", tidak ada keharusan untuk memberikan laporan pertanggungjawaban perusahaan (termasuk jumlah keuntungan) secara terbuka.

(3) Tahap ketiga, langkah pengembangan, mediasi, fasilitasi, pembinaan, dan pendampingan kelompok sasaran. Masyarakat yang belum memiliki lembaga kelompok difasilitasi untuk membentuk dan membangun lembaga kelompok. Melalui kelompok-kelompok yang ada kegiatan fasilitasi, mediasi, pembinaan, dan pendampingan dan dilakukan secara efektif dan efisien.

(4) Tahap keempat, penetapan jenis usaha dan pelaksanaan usaha ekonomi produktif yang dikembangkan. Melalui kelompok-kelompok yang sudah terbentuk, jenis usaha yang akan mereka kembangkan merupakan kesepakatan kelompok dengan mempertimbangkan potensi sum-

\section{SIMPULAN}

Pertama, kompetensi fasilitator dan faktor pendukung dapat meningkatkan perilaku berusaha masyarakat penerima program CSR. Kedua, Perilaku berusaha masyarakat mampu meningkatkan keberdayaan ekonomi rumahtangga masyarakat penerima program CSR. Ketiga, Kualitas program CSR belum mampu meningkatkan perilaku berusaha ekonomi produktif masyarakat sekitar perusahaan.

Saran. Pertama, Sebelum program CSR dijalankan, perusahaan diharapkan melakukan penyusunan program secara partisipatif (melibatkan semua pemangku kepentingan, terutama masyarakat sebagai sasaran program). Kedua, pelaksanaan program CSR sebaiknya melibatkan fasilitator (pihak ketiga) yang memiliki kompetensi di bidang kegiatan sesuai program yang dijalankan oleh perusahaan. Ketiga, perlu ditetapkan rumusan penjabaran secara operasional terhadap pasal 74 UndangUndang No. 40 Tahun 2007 tentang Perseroan Terbatas, melalui penetapan Peraturan Pemerintah atau Surat Keputusan Menteri terkait. Keempat, perlu disepakati adanya keharusan 
untuk siap diaudit oleh pihak ketiga (independen) bagi perusahaan pelaksana program CSR dalam mengalokasikan dana 2 sampai dengan 5 persen dari keuntungan perusahaan untuk menjaga akuntabilitas program CSR di wilayahnya.

\section{DAFTAR PUSTAKA}

AIMS. 2005. Corporate Social Responsibility Seminar. Jakarta: AIMS Consultant.

Badan Pusat Statistik. 2009. Statistik Industri Besar dan Sedang Provinsi Lampung Tahun 2008. Bandar Lampung: BPS.

Frederick, William C., K. Devis, dan J.E. Post. 1988. Business and Society Corporate Strategy, Public Policy, Ethics. New York: McGraw-Hill Publishing Company.

Ghozali, I., dan Fuad. 2005. Structural Equation Modeling. Semarang: Badan Penerbit Universitas Diponegoro.

Industry Canada. 2009. Corporate Social Responsibility. http://www.strategis.gc.ca. Diakses 08 September 2009.

Kotler, P., dan N. Lee. 2005. Corporate Social Responsibility: Doing the Most Good for Your Company and Your Cause. New Jersey: John Wiley \& Sons, Inc.

Nugraha, Benny Setia, Ibnu Hamad, La Tofi, Novita Hifni, dan Kasta. (Editor). 2005. Investasi Sosial. Jakarta: Puspensos LaTofi.
Nursahid, Fajar. 2006. Praktik Kedermawanan Sosial BUMN: Analisis terhadap Model Kedermawanan PT. Krakatau Steel, PT. Pertamina, dan PT. Telkom. Galang, Jurnal Filantropi dan Masyarakat Madani. Vol, 1 No, 2 Januari 2006. Halaman: 5-21. Jakarta: PIRAC

Pambudi, Teguh Sri. 2005. CSR; Sebuah Keharusan dalam Investasi Sosial. Jakarta: Puspensos - LaTofi. Hlm: 16-29

Solimun. 2002. Multivariate Analysis Structural Equation Modeling (SEM) Lisrel dan Amos. Malang: Fakultas MIPA, Universitas Brawijaya.

Sumarto, Mulyadi. 15 Agustus 2007. CSR Layaknya Buah Simalakama. Kompas: 4 (kolom 1-3).

Supranto, J. 2004. Analisis Multivariat:Arti dan Interpretasi. Jakarta: Penerbit P.T. Rineka Cipta.

Sutikno, Eddy Setiadi Soedjono, Agnes Tuti Rumiati, dan Lantip Trisunarno. Pemilihan Program Pengentasan Kemiskinan Melalui Pengembangan Model Pemberdayaan Masyarakat dengan Pendekatan Sistem. Jurnal Ekonomi Pembangunan FE UMS Volume 11, Nomor 1, Juni 2010, hlm.135-147. Surakarta: BPPE UMS.

Yollies, M.I. 1996. Critical System Thinking: Paradigm and the Modelling Space System Practice Academy of Management Journal Vol. 9, Number 6 December 1996. New York and London: Plenum Press. 